\title{
Analysis of amelogenin gene (AMGX, AMGY) expression in ameloblastoma
}

Type:

Article

Abstract:

Although the amelogenin gene is expressed in ametoblastoma, the precise expression pattern of $X$ and $Y$ amelogenin genes (AMGX, AMGY) in this tumor has not yet identified. In this study, we analyzed amelogenin gene expression in 19 samples (9 mate, 10 female) of oral amelobtastomas by RT-PCR and detect the chromosomal origin of amelogenin mRNA by restriction enzyme digestion of the RT-PCR product. All tumor samples expressed amelogenin mRNA. We could detect increased level of AMGY expression in all mate samples, higher than that of AMEX. It is an interesting finding as in normal mate tooth development, the expression of AMGY is very much lower than that of AMGX. We postulate that epigenetic change of sex chromosomes may have some correlations with tumorigenesis of ameloblastoma. We also discuss the other possible mechanisms and points for future studies on this change in expression pattern. (C) 2005 Elsevier Ltd. All rights reserved.

\begin{tabular}{|c|l|}
\hline Author & $:$ Tsujigiwa, H. \\
& $:$ Nagatsuka, H. \\
& $:$ Han, P. P. \\
& $:$ Gunduz, M. \\
& $:$ Siar, C. H. \\
& $\bullet$ Nagai, S. \\
& \\
\hline Source & Oral Oncology \\
\hline ISSN & $1368-8375$ \\
\hline DOI & $10.1016 /$ j.oraloncology.2005.04.005 \\
\hline Volume (Issue) & $41(8)$ \\
\hline Page & $843-850$ \\
\hline Year & 2005 \\
\hline
\end{tabular}

Keyword:

Amelogenin,AMGX,AMGY,ameloblastoma,RT-PCR,in situ hybridization,odontogenictumors, matrix proteins,splice products, enamel,identification,mutation,cells, end 
Please Cite As:

TSUJIGIWA, H., NAGATSUKA, H., HAN, P. P., GUNDUZ, M., SIAR, C. H., OIDA, S. \& NAGAI, N. 2005. Analysis of amelogenin gene (AMGX, AMGY) expression in ameloblastoma. Oral Oncology, 41, 843-850.

URL:

- $\quad$ http://apps.webofknowledge.com search via Accession No >>000231894300011

- http://www.ncbi.nlm.nih.gov/pubmed/15979380

- $\quad$ http://www.sciencedirect.com/science/article/pii/S1368837505001223 